\section{SOI: $1.1 /$ TAS DOI: $10.15863 /$ TAS International Scientific Journal Theoretical \& Applied Science}

p-ISSN: 2308-4944 (print) e-ISSN: 2409-0085 (online)

Year: $2015 \quad$ Issue: $12 \quad$ Volume: 32

Published: $30.12 .2015 \quad$ http://T-Science.org
Iryna Bushman

Ph.D., assistant professor of Department of Philosophy, Sociology and Innovative Social Technologies

Sumy State University,

Postdoctoral student, Institute of Higher Education, Kiev, Ukraine

bushman_irina@bigmir.net

SECTION 30. Philosophy.

\title{
MOBILITY OF PERSONALITY IN SOCIAL AND INFORMATION ENVIRONMENT
}

\begin{abstract}
The innovative character of education is an important tool for successful competition of higher school with other social institutions. Getting education is essential for the realization of these strategic objectives; accumulation and effective use of the human capital, formation of the quality characteristics of workers and their productive abilities turn them into the main productive force of modern society, which is based on knowledge.

Key words: mobility, human capital, social institution, education, information society.

Language: English

Citation: Bushman IA (2015) MOBILITY OF PERSONALITY IN SOCIAL AND INFORMATION ENVIRONMENT. ISJ Theoretical \& Applied Science 12 (32): 5-9.

Soi: http://s-o-i.org/1.1/TAS-12-32-2 Doi: crossef http://dx.doi.org/10.15863/TAS.2015.12.32.2
\end{abstract}

The strategic priorities of Ukraine are the transition to an innovative model of economic development, integration into the economic European Union and the construction of a socially responsible state. The most important condition for the implementation of these strategic objectives is the accumulation and effective use of human capital, i.e. forming the quality characteristics of workers, which shape their modern productive abilities and turn them into the main productive force of post-industrial economy, which is based on knowledge.

The experience of developed countries shows that the accumulation of human capital and ensuring its effective use is essential for the country's competitiveness and social and economic dynamic progress. Ukraine is among the countries with high educational level of the population. However, the majority of Ukrainian workers have not yet formed productive capabilities required for the dynamic and effective development of production. This indicates that the concept of human capital is not recognized enough at the state administration, on industrial and personal levels. In Ukraine, it has not become the theoretical basis for the improvement of social and economic policy and practice of management.

The formation and development of theory of human capital is associated with the names of prominent Western economists, such as G.Becker, J.Kendrick, M.Blaug, F.Maclup and others. In the Postsoviet countries this problem is represented by S.I.Ahabekov, S.Bobylev, Y.Vasylchuk, V.Ivanov,
V.Inozemtsev, V.Klochkov, V.Marcinkiewicz, V.Radayev and others.

In Ukraine, the methodological issues of human development, reproduction and use of human resources are explored by such scientists as $\mathrm{O}$. Amosha, S. Bandura, V. Brych, T. Zajac, E. Libanova, O. Novikova, V. Onikiyenko, L. Shaulska.

In the recent years, the domestic scholars pay more attention to research values and spiritual culture of students. In particular, the cultural orientation of students is analyzed in the works of T. Abolinoyi [1], N.Jincharadze, V.Kudinov, I.Zyazyuna, A.Levitsky, V.Panchenko; the spiritual and religious orientation of students is studied in the works of V.Bondarenko, P.Saukh, V.Lubska, A.Dolganov, V.Lisowski, M.Rutkiewicz, V.Chuprov, I.Shcherbakov, P.Vodopyanova and others $[2,8,9]$.

The results of the sociological study of students' community are represented in the works of A. Balakirev, E. Golovakha, N. Pobeda, I. Sheremet, A. Yakubu and others.

Modernization of education should be aimed at getting into compliance with the basic principles of market economy, transforming education into an important resource for personal, social and political development, a resource of implementation of important society and state values, which include freedom, prosperity and security. Getting education should be economically and socially effective and it should provide the expected effect. The innovative character of education is an important tool for 
successful competition of higher school with other social institutions. Today, to create a positive image of higher education for young people, it is important not only to provide the content, but also forms and technology of education.

First of all, it should be noted that a special type of world view orientation of a personality represents an important value; which is the idea about ideal, morality, goodness, and beauty, prevailing in this or that culture. "The world of values is primarily the world of culture in the broadest sense, it is the realm of people's spiritual life, their moral consciousness, their tastes, i.e. all those assessments, which express the level of spiritual wealth of the individual" [9, p.202.]. Any events and phenomena that occur in nature, society, life, are perceived not only by means of scientifically based theories, but are passed through the prism of their own attitudes. An individual compares his or her behavior to the ideal, which for them is an example. Values are the major regulator of behavior, which is best manifested in the situation of making a choice.

According to sociology, it is values that cause the formation of social institutions. From the viewpoint of psychology, a person creates values at their own discretion, and they are structured hierarchically. Everyone has their own value system: political, cultural, aesthetic, and other values. The value system is the link that connects the individual with society, including in them into the system of public relations. It specifies the reasons why this or that activity is happening, and by what means it is implemented.

Life goals, needs, interests, priorities, values in their unity form a coherent structure of personality traits, among which, the individual's values orientation is kind of an axis, and all the other components of this structure depend on them. Values orientations are one of the most important entities in the structure of human consciousness and identity, since they reflect their characteristics as a person.

In the conditions of modern Ukrainian society, a powerful tool for the formation of values of young people are media that broaden the boundaries of information space, which was common for the previous generation. This space becomes a socializing environment. The media is creating public awareness and new models of social interaction, consolidating certain forms of activity on their basis. Because of their prevalence and accessibility, media greatly influence the definition of repertoires of life scenarios and behavioral styles of young people. The media is also a tool for the spreading of mass culture. According to L.S. Shchennikova, "mass culture" severely affects people, especially the young, because it impoverishes the spiritual world. Mass culture presents a surrogate as something genuine. This leads to the fact that young people have confusing ideas and spoiled taste [15].

This can be explained by the fact that formation of the information society entails a change of value orientations in society, spreading and transmitting human values over society in general. Having a great importance alongside with the media, the Internet, a global social and communication computer network, is designed to meet personal and group communication needs through the use of telecommunication technologies.

The modern priorities of the development of education determine the need for training specialists, capable of creative work, for professional development and improvement, developing and implementation of new educational technologies. Therefore, training of teaching staff in the current environment should provide the optimal conditions for self-actualization, disclosure of their potential strength, capacities, ability to be creative, innovative, and perform operative decision-making. Considering this, it is important to train professional mobile teachers, which, taking into account the national education integration into European community, will ensure European mobility and competitiveness of a specialist.

The problem of professional mobility is a subject for sociological researching (P.Sorokin, S.Kugel, T.Zaslavskaya, R.Ryvkina, V.Shubin and others.) and economics studies (E.Ivanchenko, N.Kovalisko, S.Makeyev, E.Miroshnichenko, A.Mikhailov and others) [8, 10, 14].

The mobility of human capital is a necessary component in the system of key factors in the formation of competitive global relations. Mobility of labor force along with demographic, educational, physiological potentials is a key factor in the competitiveness of human capital. Along with the large number of definitions in terms of competitiveness, mobility should be interpreted as the ability to effect change, provide an adequate response to changes in the environment and desire to change the components of the status of human capital.

The globalization of the world economy and the labor market led to regular changes in qualitative and quantitative characteristics of human capital and potential, overall growth of competitiveness, the restructuring of national labor markets, partial reduction and disappearance of barriers between them. At the same time, globalization has led to the emergence of new, uncharacteristic for the global and national economies phenomena that have not been reflected in economic and demographic studies.

In the current domestic economic thought, the scientists traditionally pay attention to two types of mobility, which is characterized as labor mobility: 
- Territorial mobility is the process of regional population displacement for the reasons of political, economic, social, religious or personal character;

- Labor mobility is a fundamental willingness of a person to change position, profession, job, location, and lifestyle in general.

The changes introduced by the revision of the status of a person as a factor of economic reproduction and social development in a globalized world of information society and knowledge economy, suggest a simplified interpretation and a rudimentary character of limitation with exclusively territorial and labor mobility. Without being limited to stating only labor approaches, it should be noted that for the analysis of competitive human capital one should also apply developments of related sciences, among which within sociological research and evaluation processes in education the following types of mobility are distinguished:

- Social mobility, which is the transition of the individual, social object or value created or modified through human activity, from one social position to another;

- Mobility of scientific staff, which means the ability of scientists to change specialization, object of study, job, location, etc.

The presence of the distinguishing features of human capital, human resources, labor and employment potential require expanding the list of components in the definition of the mobility management tools and management mechanism of competitive human capital, the following in particular:

- Educational, which is the ability to master new knowledge obtained during labor, civic, social activities, and personal self-improvement in the learning process;

- Mental, that means loyal attitude, ability to actively implement human potential in the society, which is mentally different from person's environment;

- Personal, which is the ability to personal concentration and mobilization of resources in the implementation of their own potential;

- Innovative is the ability to modernize, upgrade and develop human potential, improving the formulation and implementation of the asset;

- Informative, which is the ability to cover the flow of information, information retrieval, its rational use;

- Aesthetic, which is the ability to design aesthetic of social behavior and interpersonal interaction within small groups $[3,8]$.

Growing competition for jobs and resources of development and reproduction of the human capital leads to changes in the nature, the accumulation of new skills and experience that objectively serve as the new life-support factors, characteristic for personal human capital, business, human capital, and social activity of human capital economy.

These changes are the factors, the basis of social mobility. That is, as a result of the intensification of international migration, along with the internationalization of production through the international division of labor, they were the key factor that led to the transformation of the phenomenon of social mobility into the determinant of competitiveness of human capital.

With the versatility of the process, the complexity management and relevant consequences, the role of social mobility in the formation of human capital cannot be overstated, given that migration factor is one of many components, leading to its activation.

The available at present results of sociological and interdisciplinary research mention the presence of two types of social mobility, intergenerational and intrinsically generational, and its two main types, vertical and horizontal. Depending on the content, the vertical mobility is identified with movement between social groups and is seen as:

- Social recovery in a case of increase of social status, which is also identified as a voluntary acquisition of attributes of a higher group;

- Reducing social status, which is identified with the forced transition to a lower social group.

Being an alternative to vertical mobility, horizontal social mobility is identified with the transition between social groups of the same level.

The direct impact of globalization on human capital is realized through the conversion of human potential that remains unused within the existing economic mechanism of national economy. That is, the arrival of multinational companies in the economy is accompanied with converting the unused national constituent entities of human potential.

The indirect effect, unlike the direct one, provokes the development of human potential components alone, creates it both on the personal level and on the state level. Only formed human potential can be converted into capital. In addition to the practical manifestations of provoking human capital development of a person, at the state level the coming of multinational corporations is accompanied with rising income and consumption, which is, basing on the multiplier effects, results in the economy of scale.

Social policy allows you to rise above the purely instrumental level and consider it in a strategic context as a policy of a higher level than, for example, fiscal, monetary, money, credit, etc., and to consider secondary social effects of measures, which are taken within the different areas of public policy. In particular, the "enhanced" interpretation allows to take into account the effect of technological change and globalization of economic relations on social policy of the national state. In this case, it is 
possible to step aside from the determinism in social policies and to consider the measures of social direction taken by enterprises, corporate and public associations etc.

The main goal of social policy is to unite society around the idea of social progress in the way of creating appropriate social relationships. Within such links, consumption of the poor should not limit the savings of the rich, but it should also play the multiplication role, stimulating economic dynamics. Obviously, the multicultural effect is possible only if the unity between costs and savings of the population is preserved, on the one hand, and companies' investments, financial and banking system, including social insurance funds, on the other. Ensuring that unity is a decisive criterion for the effectiveness of social policy. [9]

The object of social policy is the human capital of the nation - creative, professional, educational, labor, physical, reproductive potential of citizens, which is implemented in the system of socioeconomic, political, legal, cultural, ethnic and other relations, and determines the future of the nation.

For its operation, human capital needs, besides the individual investments into welfare of its owner, such as getting and improving education, health improvement, etc, their entry into economic relations with a purpose of being socially useful and obtaining resources for recreation.

Therefore, creation of conditions for stimulating the interest in investing into human capital is becoming crucially important. Given the fact that the poor quality of social services reduces their efficiency and, consequently, the propensity to invest in the social sector, public investments in social development is an important factor of activation of decentralized investments in social development. The state, providing a sufficient basic level of social security and opportunities for the effective functioning of economic actors to produce adequate income creates conditions for the development of decentralized investment in human capital.

Strengthening the state, including effective cooperation of all branches of power, can provide a breakthrough from the range of unsecured with resources declarative guarantees and their actual failure. Stability of social policy is unattainable in any way, other than actually fixing the precise level of support available to the needy population, the absolute guarantee of improving their situation and gradually increasing this level as a result of the improved economic situation.

The priority in the implementation and development of human potential belongs to labor market policies. Until recently, the balance of support in this market was in most cases provided with forced leave, wage arrears, the discrepancy remuneration for work performed.

The governmental policy in this area should be aimed primarily at developing of economic mechanisms for encouraging employers to create new jobs. The system of training and improving the quality of the labor force requires fundamental change according to the structural changes that occur in the transition economies. The state policy of labor market regulation should pay more attention to the interests of segments of this market. In particular, for the people who have personal subsidiary plots, salary plays a less important role than the other benefits of formal employment. It is about improving labor mobility, transparency of labor relations, opening of labor market to fair competition, ousting its "shadow" segments.

Conclusions. The Ukrainian scientists have made a significant contribution into the deepening of the theoretical foundations of the concept of human capital. However, many unresolved theoretical and practical problems, which are associated with human capital, should be noted, such as estimating its volume and dynamics in Ukraine; determining its impact on socio-economic development; study of the economic foundations of its formation; definition of its shares and its place in the modern structure of social capital of the country; efficiency of its practical use. This demonstrates the need for in-depth study of human capital in these areas, which is the basis for improving public policy of socio-economic development.

\section{References:}

1. Abolina TG (2004) Ethnicity and morality in the modern world. - K .: PARAPAN, 2004. $200 \mathrm{p}$.

2. Blyahman LS (1981) Mobility of person at industrial enterprise. - Kiev: Science. opinion, 1981. - $185 \mathrm{p}$.
3. Bohynya DP (1993) Methodological problems of increasing labor force competitiveness on the labor market. - Problems trudozberezhennya and social protection in Ukraine a market economy. - K .: NC ZRP, 1993. - 175 p.

4. Bondarchuk K (1996) Productive employment in conditions of social market economy // 


\begin{tabular}{|c|c|c|c|c|c|c|}
\hline Impact Factor: & $\begin{array}{l}\text { ISRA (India) } \\
\text { ISI (Dubai, UAF } \\
\text { GIF (Australia) } \\
\text { JIF }\end{array}$ & $\begin{array}{l}=1.344 \\
=0.829 \\
=0.564 \\
=1.500\end{array}$ & $\begin{array}{l}\text { SIS (USA) } \\
\text { PИНЦ (Russia) } \\
\text { ESJI (KZ) } \\
\text { SJIF (Morocco) }\end{array}$ & $\begin{array}{l}=0.912 \\
=0.179 \\
=1.042 \\
=\mathbf{2 . 0 3 1}\end{array}$ & $\begin{array}{l}\text { ICV (Poland) } \\
\text { PIF (India) }\end{array}$ & $\begin{array}{l}=6.630 \\
=1.940\end{array}$ \\
\hline
\end{tabular}

Ukraine: aspects of labor. - 1996. - № 7-9 - pp. 8-11.

5. Veyerman RK (1986) Migration to the city and social mobility // Philosophical Thought - 1986. - № 5 . - pp. 47 - 50 .

6. Dvoretska G (2002) Sociology: Training. manual. - Kind. 2nd, revised. and add. - K .: KNEU, 2002. - $472 \mathrm{p}$.

7. (1997) Life way and career path // Ed. V.I. Podshyvalkynoy. - Chisinau: IAP, 1997. - 248 p.

8. Zaslavskaya TI, Ryvkina RV (1991) Life economical sociology: Essays theory. Novosibirsk: Publishing House of the Novosibirsk State. University Press, 1991. - 442 p.

9. Zdravomyslov AG (1986) Needs. Interests. Values. - Moscow: Politizdat, 1986. - 221 p.
10. Kovalisko NV, Horonzhyy AG (2002) Regional labor mobility. - Lviv, Ivan Franko Lviv National University, 2002. - 165 p.

11. Lukashevych MP, Tulenkov MV (1999) Special and Industrial Sociological Theory: Teach. manual. - K .: AIDP, 1999. - 289 p.

12. (1974) Methodological problems of mobility of resources. - Novosibirsk: Publishing House of Novosibirsk. University Press, 1974. - 318 p.

13. Petrova IL (1996) Labor market: the process of segmentation. - K .: USPU, 1996. - 262 p.

14. Sorokyn IP (1992) Rights. Civilization. Society. - M .: Nauka, 1992. - 398 p.

15. Shchennikova LS (1999) Spiritual orienteer of the students // Social studies. - 1999. - № 8. pp. 99. 